\title{
PELATIHAN PENYUSUNAN JURNAL PENYESUAIAN PERUSAHAAN DAGANG
}

\author{
Rosmita Rasyid, Cyndy Sutanto, Shannen Evelyn Yacub \\ ${ }^{1,2,3}$ Program Studi Akuntansi, Universitas Tarumanagara Jakarta \\ Surel: rosmitar@fe.untar.ac.id
}

\begin{abstract}
This PKM aims to provide an understanding of trading company accounting, especially regarding adjusting journal entries in trading companies for students at St.Kristoforus Catholic High School. The training is carried out by providing an explanation and understanding of adjusting journals and working papers and how to fill them out. Evaluation is carried out at the end of this activity by distributing an evaluation form regarding the benefits of this activity
\end{abstract}

Keywords: Adjusting Entries, Work Sheet, Merchandising Company

\begin{abstract}
ABSTRAK
Tujuan kegiatan PKM ini adalah untuk memberikan pemahaman mengenai akuntansi perusahaan dagang khususnya mengenai ayat jurnal penyesuaian pada perusahaan dagang bagi siswa/i SMA Katolik St.Kristoforus Pelatihan ini dilakukan karena mitra merasa bahwa kemampuan akuntansi siswa/siswi mereka masih sederhana dan belum update sehingga perlu ditingkatkan Pelatihan dilakukan dengan cara memberikan penjelasan dan pemahaman mengenai jurnal penyesuaian dan kertas kerja serta cara pengisiannya. Evaluasi dilakukan di akhir kegiatan ini dengan menyebarkan form evaluasi mengenai manfaat kegiatan ini.
\end{abstract}

Kata kunci: Jurnal Penyesuaian, Kertas Kerja, Perusahaan Dagang

\section{PENDAHULUAN}

Setiap organisasi menginginkan dapat hidup dan berkembang dalam jangka panjang termasuk organisasi pendidikan. Agar dapat eksis dalam jangka panjang maka organisasi pendidikan tersebut terus berupaya memperbaiki bekal ilmu yang diberikan peserta didiknya atau dengan kata lain setiap organisasi pendidikan tentunya menginginkan agar peserta yang dididik dapat memperoleh ilmu pengetahuan yang bermanfaat bagi peserta didiknya.

Sekolah Katolik St.Kristoforus merupakan sebuah organisasi pendidikan yang mendidik siswa/i SMA yang berada di Grogol Jakarta Barat. SMA ini didirikan dengan misi untuk mencerdaskan anak didik yang mendukung program pemerintah untuk mencerdaskan kehidupan bangsa.

Sekolah SMA Katolik St.Kristoforus berusaha membekali siswa/inya dengan ilmu pengetahuan yang diharapkan dapat bermanfaat bagi siswa/i dalam menjalani kehidupan mereka kelak. Salah satu materi yang dirasakan dibutuhkan adalah materi tentang akuntansi khususnya penyediaan Laporan Keuangan Perusahaan Jasa maupun Perusahaan Dagang.

Laporan keuangan merupakan laporan akuntansi yang mengkomunikasikan informasi mengenai perusahaan kepada pihak-pihak yang berkepentingan dengan perusahaan (IAI,2018). Agar informasi dalam laporan keuangan dapat difahami oleh pihak-pihak yang berkepentingan dengan perusahaan, maka data yang dilaporkan haruslah berdasarkan suatu standar. Standar itu di Indonesia adalah Standar Akuntansi Keuangan (SAK) yang disusun oleh Ikatan Akuntansi Indonesia (IAI) Laporan keuangan merupakan kumpulan informasi yang dihasilkan dari transaksi yang sama. Misalnya penjualan yang dilaporkan dalam Laporan Keuangan adalah semua transaksi penjualan dalam satu periode tersebut. Laporan keuangan berisi informasi keuangan perusahaan terkait kinerja perusahaan dalam satu periode maupun informasi mengenai posisi keuangan perusahaan pada saat itu (Kartikahadi, 2016). 
Proses penyediaan Laporan Keuangan untuk satu periode tertentu sangat terkait dengan siklus akuntansi. Siklus akuntansi meliputi 9 tahap (Kieso et al, 2018) dimulai dengan 1) melakukan analisis transaksi bisnis, 2) membuat jurnal transaksi, 3) memposting kedalam buku besar, 4) membuat Neraca Saldo, 5) menjurnal dan memposting ayat jurnal penyesuaian, 6) membuat Neraca Saldo yang telah disesuaikan, 7) membuat Laporan Keuangan, 8) menjurnal dan memposting ayat jurnal penutup, dan 9) menyusun Neraca Saldo Sesudah Penutupan. Tahap 4, 5 dan 6 akan lebih mudah dilakukan apabila dibuatkan worksheet (kertas kerja). Setelah selesai tahap 9 maka dapat dimulai Tahap 1 periode selanjutnya.

\section{METODE PELAKSANAAN PKM}

Peningkatan kemampuan akuntansi siswa/i SMA Katolik St.Kristoforus ini amat terkait dengan satu siklus akuntansi baik pada perusahaan jasa maupun perusahaan dagang. Siklus akuntansi berawal dari melakukan analisis atas transaksi bisnis dan diakhiri dengan menyusun Neraca Saldo Sesudah Penutupan (Dewi, 2018).

Pelaksanaan PKM dilakukan dengan metode pemberian pemahaman mengenai siklus akuntansi yang termasuk didalamnya pemberian pemahaman jurnal penyesuaian. Kegiatan Pengabdian Masyarakat ini dikemas dalam bentuk ceramah, diskusi dan pemecahan masalah mengenai pemahaman pajak bagi orang pribadi. Evaluasi dilakukan di akhir kegiatan ini dengan menyebarkan form evaluasi mengenai manfaat kegiatan ini. PKM ini dilaksanakan secara daring dengan platform zoom. Pembicara dalam kegiatan ini dosen FEB prodi Akuntansi Untar dengan dibantu oleh 2 orang mahasiswa.

\section{HASIL DAN PEMBAHASAN}

Pemahaman mengenai jurnal penyesuaian pada perusahaan dagang haruslah berangkat dari pemahaman mengenai siklus akuntansi. Secara terperinci siklus akuntansi berawal dari melakukan analisis atas transaksi bisnis, mencatat transaksi ke dalam jurnal dan kemudian diposting ke buku besar. Sesudah diposting ke buku besar, maka dapat disusun Neraca Saldo pada akhir periode, selanjutnya harus dibuat jurnal penyesuaian dan diposting ke buku besar dan disusun Neraca Saldo Sesudah Penyesuaian sehingga dapat disusun Laporan Keuangan. Untuk dapat memulai siklus akuntansi periode berikutnya, maka dibuat jurnal penutup serta diposting kedalam buku besar sehingga dapat disusun Neraca Saldo Sesudah Penutupan. Agar memudahkan pelaksanaan siklus akuntansi periode berikutnya, dapat dibuat Jurnal Pembalik.

Pada PKM ini membahas mengenai ayat jurnal penyesuaian pada perusahaan dagang. Akun yang digunakan oleh perusahaan dagang lebih banyak daripada akun-akun yang digunakan oleh perusahaan jasa. Adapun bentuk badan usaha yang dijadikan contoh adalah berupa Perseroan Terbatas (PT). Akun-akun perusahaan dagang (asumsi menggunakan sistem pencatatan perpetual) yang berbeda dari perusahaan jasa adalah akun-akun: (a) Inventory; (b)Sales; (c) Sales Return and Allowances; (d) Sales Discount dan; (e) Cost of Goods Sold.

Setelah transaksi dicatat didalam jurnal dan diposting ke buku besar, maka disusun Neraca Saldo. Neraca Saldo ini disebut Neraca Saldo Sebelum Penyesuaian. Mengapa disebut demikian? Karena neraca saldo tersebut membutuhkan penyesuaian untuk beberapa akun, agar akun dalam neraca saldo tersebut mencerminkan kondisi yang sesungguhnya/kondisi rielnya.

Jurnal penyesuaian diklasifikasikan menjadi 2 yakni Penangguhan (Deferral) dan Akrual (Accruals). Jurnal penyesuaian Penangguhan terdiri dari 1) Beban dibayar dimuka (Prepaid expenses) Beban-beban telah dibayarkan kasnya sebelum dipakai atau menjadi beban. 2) Pendapatan yang diperoleh dimuka (Unearned revenues) Uang kas telah diperoleh sebelum jasa diselesaikan atau dikerjakan. Sebaliknya jurnal penyesuaian. Akrual terdiri dari 1) Pendapatan akrual yakni Pendapatan atas jasa yang telah diberikan tetapi kasnya belum diterima atau belum 
dilakukan pencatatan. 2) Beban akrual yakni beban yang sudah terjadi tetapi kasnya belum dibayarkan atau belum dilakukan pencatatan.

Secara umum jurnal penyesuaian pada perusahaan dagang memiliki jurnal penyesuaian yang sama dengan perusahaan jasa, namun ada penyesuaian tambahan yang dibutuhkan oleh perusahaan dagang. Penambahan tersebut terkait dengan persediaan barang dagang, piutang dagang dan penyesuaian lainnya yang dibutuhkan.

Penyesuaian untuk persediaan barang dagang dapat digambarkan sebagai berikut:

Pada akhir periode, untuk meyakinkan bahwa persediaan barang dagang yang ada pada catatan sesuai dengan kondisi riilnya di gudang maka perusahaan melakukan penghitungan fisik persediaan. Apabila terjadi perbedaan antara nilai barang dagang pada kondisi riilnya dengan nilai barang dagang yang ada pada catatan perusahaan, maka harus dibuat sebuah jurnal penyesuaian. Misalnya nilai barang dagang pada akhir periode, yang ada pada catatan perusahaan sebesar Rp 3.000.000, sedangkan hasil penghitungan fisik barang dagang adalah Rp 2.800.000. Hal ini berarti ada perbedaan sebesar Rp 200.000. Perbedaan ini bisa disebabkan oleh barang ada yang rusak, usang, kecurian dan sebagainya, maka jurnal penyesuaian yang harus dibuat perusahaan adalah dengan mendebetkan Harga Pokok Penjualan 200.000 dengan mengkreditkan Persediaan Barang Dagang 200.000.

Jurnal penyesuaian yang dibuat di atas adalah dengan asumsi perusahaan menggunakan sistem pencatatan perpetual. Pada perusahaan yang menggunakan sistem pencatatan persediaan barang dangan dengan sistem periodik, maka jurnal penyesuaian yang dibuat berbeda dari jurnal penyesuaian di atas.

Hal ini disebabkan pada sistem pencatatan perpetual terdapat akun harga pokok penjualan dimana setiap kali terjadi penjualan, maka harga pokok penjualan dari barang dagang yang terjual akan dicatat dengan mendebetkan akun harga pokok penjualan tersebut dan mengkreditkan akun persediaan barang dagang. Hal ini berakibat pada saldo akun harga pokok penjualan yang terdapat dalam buku besar akan selalu merupakan akumulasi harga pokok penjualan pada suatu periode dan akun persediaan barang dagang akan mencerminkan nilai persediaan pada kondisi terakhir. Jurnal penyesuaian yang dibuat pada akhir periode hanyalah dibuat apabila terjadi sedikit perbedaan antara nilai persediaan barang dagang yang tercatat dengan nilai persediaan barang dagang dari hasil penghitungan fisik persediaan barang dagang.

Pada sistem pencatatan periodik, pembelian dan penjualan persediaan barang dagang tidak dilakukan pencatatan atas mutasi persediaan barang dagang tersebut. Hal ini berakibat pada nilai persediaan barang dagang yang terdapat dalam Neraca Saldo adalah merupakan nilai persediaan barang dagang pada awal periode. Hal ini tentunya tidak mencerminkan kondisi nilai persediaan barang dagang yang sesungguhnya. Untuk itu perlu dibuat jurnal penyesuaian pada akhir periode. Jurnal penyesuaian ini dibuat untuk menjadikan nilai persediaan barang dagang menjadi nilai persediaan barang dagang pada akhir periode. Nilai persediaan barang dagang pada akhir periode ditentukan berdasarkan hasil penghitungan fisik persediaan pada akhir periode. Jurnal penyesuaian dibuat untuk menghilangkan nilai persediaan barang dagang awal dan menimbulkan nilai persediaan barang dagang akhir. Cara untuk menghilangkan nilai persediaan barang dagang yang bernilai awal periode adalah dengan mendebetkan akun sementara yakni akun Ikhtisar Laba-rugi dan mengkreditkan akun Persediaan barang dagang dengan nilai awal periode. Selanjutnya untuk menimbulkan nilai persediaan barang dagang dengan nilai akhir periode adalah dengan mendebetkan akun persediaan barang dagang dengan nilai akhir periode dan mengkreditkan akun Ikhtisar Laba-rugi.

Penyesuaian selanjutnya yang kemungkinan terjadi adalah atas penyisihan piutang tak tertagih. Piutang dapat timbul apabila perusahaan melakukan penjualan barang dagang tidak secara tunai, melainkan secara kredit. Selalu terdapat kemungkinan bahwa piutang tidak dapat tertagih semuanya. Untuk keperluan penyusunan laporan keuangan, piutang harus dinilai sebesar jumlah 
yang diharapkan dapat diterima. Contoh cara pembuatan jurnal penyesuaian untuk penyisihan piutang tak tertagih dapat dilakukan dengan menghitung berapa penyisihan piutang tak tertagih yang akan dibentuk. Setelah ditetapkan berapa penyisihan piutang tak tertagih, selanjutnya adalah membuat jurnal penyesuaian dengan mendebetkan akun beban piutang tak tertagih dan mengkreditkan akun penyisihan piutang tak tertagih. Akun penyisihan piutang tak tertagih merupakan akun kontra dari akun piutang.

Penyesuaian juga dapat dilakukan untuk bunga bank atas pinjaman yang belum jatuh tempo. Contoh tanggal 1 Desember perusahaan meminjam uang ke bank untuk jangka waktu setahun. Apabila perusahaan menyusun laporan keuangan pada tanggal 31 Desember, maka sudah ada bunga bank yang terhutang untuk periode satu bulan. Maka jurnal penyesuaian yang harus dibuat adalah dengan mendebetkan akun beban bunga dan mengkreditkan akun hutang bunga.

Setelah jurnal penyesuaian dibuat, maka Neraca Saldo sesudah Penyesuaian dapat dibuat. Neraca saldo sesudah penyesuaian merupakan dasar untuk menyusun laporan keuangan. Penggunaan Neraca Lajur (Worksheet) Neraca lajur memudahkan perusahaan dalam menyusun laporan keuangan. Angka Neraca Saldo diambil dari saldo akun-akun yang ada pada ledger perusahaan. Akun yang digunakan oleh perusahaan dagang lebih banyak daripada akun-akun yang digunakan oleh perusahaan jasa. Adapun bentuk badan usaha yang dijadikan contoh adalah berupa Perseroan Terbatas (PT). Akun-akun perusahaan dagang (asumsi menggunakan sistem pencatatan perpetual) yang berbeda dari perusahaan jasa adalah akun-akun: (a) Inventory; (b)Sales; (c) Sales Return and Allowances; (d) Sales Discount dan; (e) Cost of Goods Sold. Bentuk kertas kerja terlihat dalam tabel 1 di bawah ini:

\section{Tabel 1. Kertas Kerja}

PT Rina

Worksheet

For the Year Ended Desember 31, 20..

Trial Balance Adjustment Adjusted TB Income Sta Statement of Fin Position

Account Titles Dr. Cr. Dr. Cr. Dr. Cr. Dr. Cr. Dr. $\mathrm{Cr}$

\section{KESIMPULAN}

Kemampuan akuntansi siswa/i SMA Katolik St.Kristoforus dapat ditingkatkan dengan memberikan pemahaman yang dimulai dari satu siklus akuntansi perusahaan dagang. PKM ini mengenai pemberian pemahaman mengenai ayat jurnal penyesuaian pada perusahaan dagang. Penyesuaian diperlukan karena ada beberapa nilai akun di dalam Neraca Saldo yang belum mencerminkan kondisi yang sesungguhnya. Penyesuaian pada perusahaan dagang serupa dengan penyasuaian yang dilakukan pada perusahaan jasa namun ada penambahan penyesuaian terkait piutang dagang dan persediaan barang dagang.

\section{Ucapan Terima Kasih}

Ucapan terima kasih kami haturkan kepada pihak-pihak yang memudahkan kami menyelesaikan tugas PKM ini terutama kepada LPPM Untar.

\section{REFERENSI}

Dewi, Sofia Prima; Tjhai Fung Jin, Elizabeth Sugiarto, Merry Susanti (2018) Panduan Belajar Pengantar Akuntansi, In Media

Ikatan Akuntan Indonesia (2018), Standar Akuntansi Keuangan

Ikatan Akuntan Indonesia (2018), Standar Akuntansi Keuangan Entitas Tanpa Akuntabilitas Publik 
Kartikahadi, Hans, dkk., (2016). Akuntansi Keuangan Berdasarkan SAK Berbasis IFRS Buku 1. Edisi kedua. Jakarta: Ikatan Akuntan Indonesia (IAI)

Kieso, Donald E, Jerry J Weygandt, Terry D. Warfield, (2018) Intermediate Accounting, IFRS Edition, Third Edition, USA: John Wiley \& Sons, Inc.

Weygandt, Jerry J., Paul D. Kimmel, and Donald E. Kieso. (2015).Financial Accounting, IFRS Edition.3rd Edition. USA: John Wiley \& Sons, Inc. 
Seminar Nasional Hasil Penelitian dan Pengabdian Kepada Masyarakat 2021

Pengembangan Ekonomi Bangsa Melalui Inovasi Digital Hasil Penelitian dan

Pengabdian Kepada Masyarakat

Jakarta, 21 Oktober 2021

(halaman kosong) 